\title{
PENAMPILAN 10 AKSESI TALAS (Colocasio esculenta (L). Schott) DI LAHAN PESISIR BENGKULU
}

\author{
Ramalan Manahara Simamora $^{1}$, Yulian $^{1 *}$, Edhi Turmudi $^{1}$ \\ ${ }^{1}$ Program Studi Agroekoteknologi, Fakultas Pertanian, Universitas Bengkulu \\ *Corresponding Author : yulian@unib.ac.id
}

\begin{abstract}
[MORPHOLOGICAL CHARACTERIZATION OF 10 TARO (Colocasia esculenta (L). Schott) ACCESSION ON COASTAL AREA]. Taro is a tropical crop and contained a wide range of genetic and morphological diversity. This study was aimed to characterize the morphology of 10 taro accessions collected from different areas. The experiment was conducted at coastal area of the City of Bengkulu $( \pm 14$ above sea level). The accessions $(\mathrm{T} 1=$ Talas Hitam, $\mathrm{T} 2=$ Talas Minyak, T3 $=$ Talas Ketan, T4 $=$ Talas Bogor, T5 $=$ Talas Enggano 2, T6 $=$ Talas Merpati, T7 = Talas Cimpul Hijau, T8 = Talas Jepang, T9 = Talas Enggano 1, T10 = Talas Melati) were grown on $1 \mathrm{~m}$ x $2 \mathrm{~m}$ experimental units arranged in a randomized complete block design with three replications. Results indicated that the accession could be distinguished into three groups of stem colors (white: T2, T4, T5, T6, T7, T8, and T9; pale pink: T1 and T3; reddish orange: T10), three groups of leaf colors (green: T2, T3, T4, T5, T6, T8, T9, and T10; dark green: T7; and purplish green: T1), four group of leaf shapes (shield: T1 and T6, delta : T2, T3, and T7, Oval : T5, T8, T9, and T10; heart: T4); three groups of leaf tips (pointed: T1, T2, T3, T4, T9, and T10; blunt: T5, T6, and T7; rounded: T8); two groups of leaf edges (wavy: T1, T2, T3, T5, T6, T8, T9, and T10; flat: T4 and 7); and five groups of petiole colors (green: T2, T4, and T10; yellowish green: T5,T8, and T9; bluish green: T7; purplish green: T3 and T6; black: T1). The analysis of variance showed significant differences among the accessions for plant height, leaf greenness, pseudo stem diameter, and tiller number.
\end{abstract}

Keyword: taro, qualitative characters, quantitative characters, coastal area

\begin{abstract}
ABSTRAK
Talas (Colocasio esculenta (L). Schott) merupakan tanaman tropis dan memiliki keragamam genetik maupun morfologi yang besar. Penelitian ini pertujuan untuk mengidentifikasi ciri morfologis dari 10 aksesi talas yang dikumpulkan dari berbagai daerah. Percobaan dilaksanakan di daerah pesisir Kota Bengkulu ( \pm 14 dpl). Talas terdiri atas 10 aksesi yaitu T1 = Talas Hitam, T2 = Talas Minyak, T3 $=$ Talas Ketan, T4 = Talas Bogor, T5 = Talas Enggano 2, T6 = Talas Merpati, T7 = Talas Cimpul Hijau, T8 = Talas Jepang, T9 $=$ Talas Enggano $1, \mathrm{~T} 10=$ Talas Melati ditanam pada satuan-satuan percobaan berukuran $1 \mathrm{~m}$ x $2 \mathrm{~m}$ yang disusun dalam rancangan acak kelompok lengkap dengan tiga ulangan. Hasil penelitian menunjukkan bahwa aksesi-aksesi tersebut dapat dibedakan menjadi tiga kelompok warna batang (putih: T2, T4, T5, T6, T7, T8, dan T9; pink pucat: T1 dan T3; orange kemerahan: T10); tiga kelompok warna daun (hijau: T2, T3, T4, T5, T6, T8, T9, dan T10; hijau gelap: T7; dan hijau keunguan: T1), empat kelompom bentuk daun (perisai: T1 dan T6, delta : T2, T3, dan T7, Oval : T5, T8, T9, dan T10; hati: T4); tiga kelompok ujung daun (runcing: T1, T2, T3, T4, T9, dan T10; tumpul: T5, T6, dan T7; bundar: T8); dua kelompok tepi daun (bergelombang: T1, T2, T3, T5, T6, T8, T9, dan T10; datar: T4 dan 7); dan lima kelompok wana tangkai daun (hijau: T2, T4, dan T10; hijau kekuningan: T5,T8, dan T9; hijau kebiruan: T7; hijau keunguan: T3 dan T6; hitam: T1). Analisis varian menunjukkan keragaman yang nyata antar aksesi pada tinggi tanaman, tingkat kehijauan daun, batang semu, dan jumlah anakan.
\end{abstract}

Kata kunci: talas, variabel kualitatif, variabel kuantitatif 


\section{PENDAHULUAN}

Talas (Colocasia esculenta (L.) Schott) merupakan salah satu komoditas pangan yang memiliki banyak kegunaan. Selain itu talas juga bernilai ekonomis tinggi yang cukup menguntungkan sebagai sumber karbohidrat, lemak, vitamin dan terdapat kandungan serat yang sangat baik. Talas termasuk makanan yang rendah kalori dan menjadi konsumsi alternatif sebagai pengganti nasi dan dapat menormalkan gula darah bagi penderita diabetes. Pada saat ini kebanyakan talas hanya dimanfaatkan sebagai olahan sederhana seperti keripik talas, padahal dari segi manfaat lebih baik talas diolah dalam bentuk pati karena dapat dimanfaatkan sebagai bahan pengganti dalam pembuatan cake dan kue-kue lainnya (Hartati \& Prana, 2003).

Lahan pesisir luas untuk pengembangan tanaman talas. Namun demikian luasan lahan tersebut belum dimanfaatkan secara optimal. Indonesia memiliki panjang garis pantai mencapai $106.000 \mathrm{~km}$ dengan potensi luas lahan 1.060 .000 ha, sehingga jika dimanfaatkan untuk budidaya akan menjadi prospek yang baik untuk pengembangan pertanian (Yuwono, 2009). Lahan pesisir adalah hamparan tanah pasiran yang berada di sepanjang garis pantai. Lahan pesisir umumnya mempunyai sifat tanah yang tidak stabil, lengas tanah rendah, evapotranspirasi tinggi, kandungan garam tinggi, dan rendah kandungan bahan organik (Sumardi, 2008; Shi et al., 2005). Kapasitas Tukar Kation (KTK), C-organik dan Ca yang sangat rendah, daya mengikat air rendah (Rajiman et al., 2008), kekurangan unsur nitrogen (Sunardi \& Sarjono, 2007; Cornell et al., 2003), serta luas permukaan yang kecil dan pori yang besar (Sitorus et al., 2008) yang menyebabkan kapasitas menahan air menjadi rendah.

Penelitian terdahulu tentang talas menggambarkan bahwa banyak varietas yang tersebar di beberapa wilayah Indonesia. Varietas-varietas tersebut ada warna umbinya putih, krem, kuning, orange, merah muda, ungu dan merah (Setyowati et al., 2007). Demikian pula berdasarkan bentuk batang, warna daun, bentuk daun, ujung daun, tepi daun, warna tangkai daun, dan rasa umbi yang beranekaragam (Hafsah et al., 2014), warna bunga tanaman talas (Prana, 2007). Sehubungan dengan hal tersebut Sumarno (1985) menyatakan bahwa setiap genotipe itu memiliki ciri-ciri khusus yang seragam dan stabil serta mengandung perbedaan yang jelas dari genotipe lain. Hasil penelitian Suharno (2010) menunjukkan bahwa faktor yang mempengaruhi rendahnya produksi umbi talas antara lain; populasi tanaman rendah per satuan luas, beragam variasi umbi, dan jenis media tanah yang digunakan.

Penelitian ini pertujuan untuk mengidentifikasi ciri morfologis dari 10 aksesi talas yang dikumpulkan dari berbagai daerah.

\section{METODE PENELITIAN}

Penelitian ini dilaksanakan pada bulan Juni sampai Agustus 2015 di Kelurahan Sukamerindu, Kecamatan Sungai Serut, Kota Bengkulu pada ketinggian tempat $\pm 14 \mathrm{~m} \mathrm{dpl}$. Alat yang digunakan dalam penelitian ini ialah cangkul, parang, ember, penggaris, meteran, gembor, kamera, waring, bambu, color chart book, mikroskop, lem isolasi, kutek, kertas label dan alat tulis. Sedangkan bahan yang digunakan yaitu bibit talas dari 10 aksesi, jerami padi, pupuk kandang sapi, pupuk Urea, $\mathrm{KCl}$, dan TSP.

Penelitian ini menggunakan Rancangan Acak Kelompok Lengkap (RAKL) dengan faktor tunggal yang terdiri atas 10 aksesi talas yaitu $\mathrm{T} 1=$ Talas Hitam, $\mathrm{T} 2=$ Talas Minyak, $\mathrm{T} 3=$ Talas Ketan, T4= Talas Bogor, T5 $=$ Talas Enggano 2, T6 $=$ Talas Merpati, T7 $=$ Talas Cimpul Hijau, T8 =Talas Jepang, T9=Talas Enggano 1, $\mathrm{T} 10=$ Talas Melati. Masing-masing perlakuan diulang 3 kali sehingga diperoleh total 30 unit percobaan.

Pengolahan lahan diawali dengan pembersihan lahan atas gulma yang tumbuh, kemudian dilanjutkan pengolahan tanah pertama dan kedua. Lahan percobaan yang telah diolah dan dibersihkan dari gulma dibagi menjadi 30 petak yang masing-masing berukuran $1 \mathrm{~m} \times 2 \mathrm{~m}$, jarak antar petak $50 \mathrm{~cm}$ dan jarak antar blok $75 \mathrm{~cm}$. Tanaman diberi pupuk kandang sapi satu minggu sebelum bibit ditanam dengan mencampurkan ke dalam tanah dengan dosis $2 \mathrm{~kg} /$ petak.

Bibit talas ditanam tegak di bawah permukaan tanah dengan satu bibit per lubang tanam, sehingga jumlah tanaman per petak terdapat 8 tanaman. Masing-masing petak diberi mulsa organik jerami padi.

Pemeliharaan yang dilakukan meliputi pengairan, penyulaman, pemupukan, pengendalian gulma dan pengendalian hama penyakit. Pengairan tanaman dilakukan setiap hari apabila hari tidak hujan. Pengairan dilakukan pada sore hari untuk menjaga kelembaban tanah dan mencukupkan kebutuhan air tanaman. Penyulaman dilakukan pada 20 hst terhadap tanaman yang mati dan pertumbuhannya kurang baik. Pemupukan dilakukan sebanyak satu kali yaitu pada saat tanaman berumur satu bulan dengan pupuk anjuran Urea 55 $\mathrm{kg} / \mathrm{ha}$, TSP $55 \mathrm{~kg} / \mathrm{ha}$ dan KCl $73 \mathrm{~kg} / \mathrm{ha}$ (Nurlisan et al., 2014) Pengendalian gulma dan hama yang menyerang dilakukan secara manual.

Variabel pengamatan terdiri atas 2 variabel yaitu variabel kualitatif dan variabel kuantitatif. Menurut PPVT (2006) yang termasuk variabel kualitatif yaitu warna batang, bentuk daun, ujung daun, tepi daun, warna daun, dan warna tangkai daun. Sedangkan variabel kuantitatif terdiri atas tinggi tanaman, tingkat kehijauan daun, diameter batang semu, jumlah daun, jumlah anakan, jumlah akar, bobot berangkasan segar, kerapatan stomata 
Data kuantitatif dianalisis secara statistik dengan analisis varian (ANAVA). Untuk membandingkan rata-rata antar aksesi talas dilakukan Duncan Multiple Range Test (DMRT) pada taraf 5\% (Yitnosumarto, 1991). Data kualitatif disajikan secara deskriptif.

\section{HASIL DAN PEMBAHASAN}

Berdasarkan pengamatan variabel kualitatif talas atas dasar umbinya dibedakan menjadi dua yaitu umbi bonggol dan umbi stolon (Gambar 1). Dari 10 aksesi yang diamati ada 4 aksesi talas umbi bonggol yaitu Talas Enggano 1, Talas Enggano 2, Talas Bogor, Talas Melati dan 6 aksesi umbi akar yaitu Talas Hitam, Talas Minyak, Talas Ketan, Talas Merpati, Talas Jepang, dan Talas Cimpul 1.

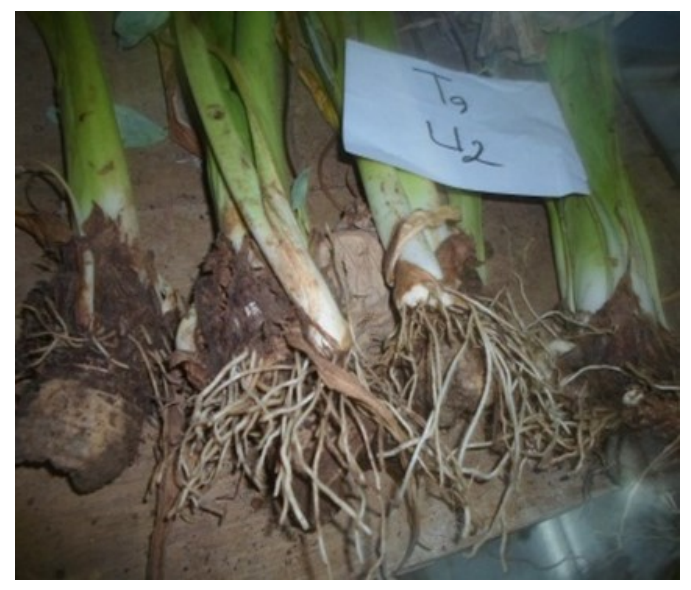

Gambar 1a. Umbi bonggol

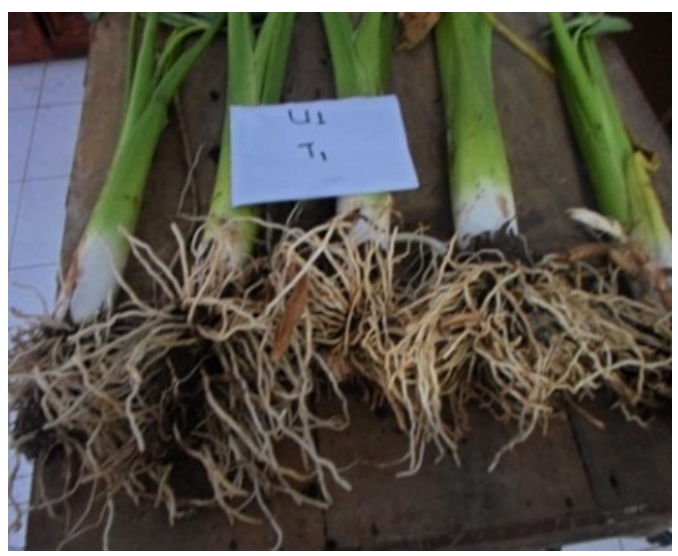

Gambar 1b. Umbi Stolon

Variabel kualitatif yang diamati pada sepuluh aksesi talas yaitu warna batang, warna daun, bentuk daun, ujung daun, tepi daun, dan warna tangkai daun. Warna batang pada 10 aksesi talas adalah putih, pink pucat dan orange kemerah mudaan. Hasil pengamatan menunjukkan ada tujuh aksesi talas berwarna putih (N9), dua aksesi berwarna pink pucat (5R 8/2), dan satu aksesi berwarna orange kemerah mudaan
(10R 7/4). Menurut Somantri et al. (2001) warna batang talas ada putih, putih kemerahan, pink pucat dan orange kemerah mudaan.

Wama daun pada 10 aksesi tanaman talas ialah hijau, hijau tua, hijau keunguan. Terdapat delapan aksesi talas berwarna hijau (4/6 $5 G Y)$, satu aksesi warna daun berwarna hijau tua (10 GY 3/2), dan satu aksesi berwarna daun hijau keunguan (10 GY 5/2). Warna daun dipengaruhi oleh kandungan klorofil pada daun, sehingga semakin tinggi kandungan klorofil daun tanaman maka akan semakin pekat warna daun yang dimiliki. Menurut Paiki et al. (1998) warna daun talas ada hijau, hijau tua, ungu, keunguan, dan hijau keunguan.

Bentuk daun talas pada 10 aksesi talas yaitu perisai, delta, oval, dan hati. Dua aksesi berbentuk daun perisai, tiga aksesi berbentuk daun delta, empat aksesi bentuk daun oval, dan satu aksesi bentuk daun hati. Menurut Paiki et al. (1998) bentuk-bentuk daun talas seperti perisai, delta, oval, dan hati.

Ujung daun talas pada 10 aksesi talas yaitu runcing, tumpul, dan bundar. Enam aksesi ujung daun runcing, tiga aksesi ujung daun tumpul, dan satu aksesi ujung daun bundar. Menurut Somantri et al. (2001) ujung daun talas ada yang runcing, tumpul, bundar, dan bulat.

Tepi daun talas pada 10 aksesi talas adalah bergelombang dan rata. Delapan aksesi tepi daun bergelombang, dan dua aksesi tepi daun rata. Menurut Paiki et al. (1998) tepi daun talas ada yang bergelombang, dan ada yang rata.

Warna tangkai daun talas pada 10 aksesi talas adalah hijau, hijau kekuningan, hijau kebiruan, hijau keunguan, kehitaman. Tiga aksesi talas warna tangkai daun berwarna hijau (4/6 5GY), tiga aksesi warna tangkai daun berwarna hijau kekuningan (7/4 $5 G Y$ ), satu aksesi warna tangkai daun berwarna hijau kebiruan (6/8 $5 G Y)$, dua aksesi warna tangkai daun berwarna hijau keunguan (10 Y 5/2), dan satu aksesi warna tangkai daun berwarna hitam (N1). Menurut Paiki et al. (1998) warna tangkai daun ada hijau, hijau tua, hijau kekuningan, hijau kebiruan, hijau keunguan, dan kehitaman. Warna tangkai daun dipengaruhi oleh intensitas cahaya yang mengatur pigmen dalam jaringan epidermis atau parenkim pada batang. Pigmen yang berperan dalam menentukan warna tangkai daun adalah pigmen antosianin. Adanya pigmen antosianin menyebabkan warna tangkai daun cenderung gelap, sedangkan jika tidak terdapat pigmen antosianin menyebabkan warna tangkai daun menjadi terang (Grist, 1986).

Hasil pengamatan didapat satu aksesi talas berbunga secara alami 83 hari yaitu Talas Merpati (Gambar2). Munculnya bunga talas didahului oleh keluarnya daun bendera, yaitu daun yang mengalami modifikasi karena pelepahnya menjadi lebih pendek dan helai daunnya jauh lebih kecil ukurannya dari pada daun biasa. Hasil pengamatan variabel kualitatif dari 10 aksesi talas seperti terlihat pada pada Tabel 1 . 
Tabel 1. Hasil pengamatan variabel kualitatif

\begin{tabular}{|c|c|c|c|c|c|c|}
\hline $\begin{array}{l}\text { Genotipe } \\
\text { talas }\end{array}$ & Warna batang & $\begin{array}{l}\text { Warna } \\
\text { daun }\end{array}$ & $\begin{array}{l}\text { Bentuk } \\
\text { daun }\end{array}$ & $\begin{array}{l}\text { Ujung } \\
\text { daun }\end{array}$ & Tepi daun & $\begin{array}{l}\text { Warna } \\
\text { tangkai } \\
\text { daun }\end{array}$ \\
\hline Hitam & Pink pucat & $\begin{array}{l}\text { Hijau } \\
\text { keunguan }\end{array}$ & Perisai & Runcing & Bergelombang & Hitam \\
\hline Minyak & Putih & Hijau & Delta & Runcing & Bergelombang & Hijau \\
\hline Ketan & Pink pucat & Hijau & Delta & Runcing & Bergelombang & $\begin{array}{l}\text { Hijau } \\
\text { keunguan }\end{array}$ \\
\hline Bogor & Putih & Hijau & Hati & Runcing & Rata & Hijau \\
\hline Enggano 2 & Putih & Hijau & Oval & Tumpul & Bergelombang & $\begin{array}{l}\text { Hijau } \\
\text { kekuningan }\end{array}$ \\
\hline Merpati & Putih & Hijau & Perisai & Tumpul & Bergelombang & $\begin{array}{l}\text { Hijau } \\
\text { keunguan }\end{array}$ \\
\hline Cimpul & Putih & Hijau tua & Delta & Tumpul & Rata & $\begin{array}{l}\text { Hijau } \\
\text { kebiruan }\end{array}$ \\
\hline Jepang & Putih & Hijau & Oval & Bundar & Bergelombang & $\begin{array}{l}\text { Hijau } \\
\text { kekuningan }\end{array}$ \\
\hline Enggano 1 & Putih & Hijau & Oval & Runcing & Bergelombang & $\begin{array}{l}\text { Hijau } \\
\text { kekuningan }\end{array}$ \\
\hline Melati & $\begin{array}{l}\text { Orange kemerah } \\
\text { mudaan }\end{array}$ & Hijau & Oval & Runcing & Bergelombang & Hijau \\
\hline
\end{tabular}

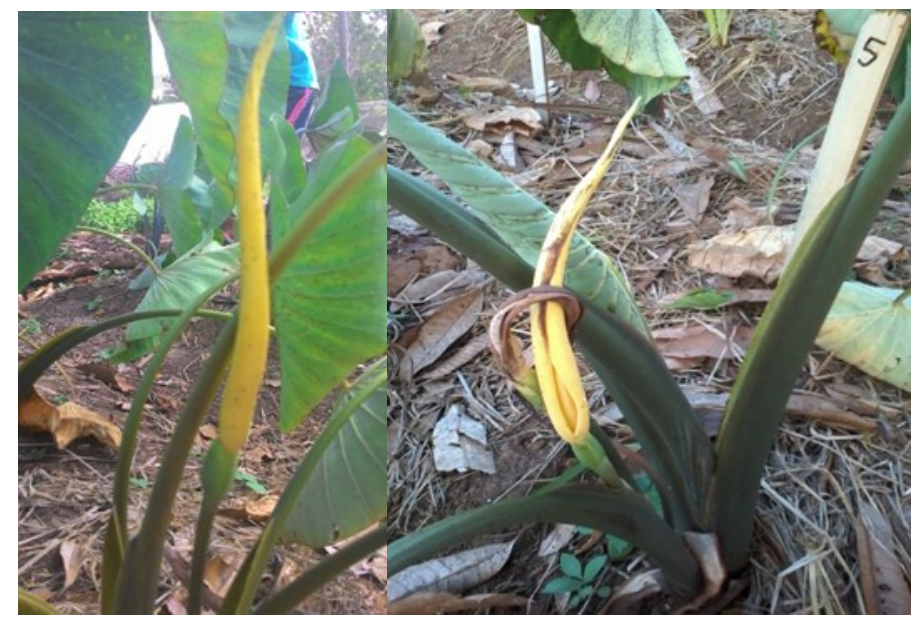

Gambar 2. Bunga talas

Hasil analisis keragaman pada variabel kuantitatif menunjukkan bahwa terdapat perbedaan nyata $(\mathrm{P}<0,05)$ antar aksesi terhadap tinggi tanaman, tingkat kehijauan daun, diameter batang semu dan jumlah anakan. Namun terhadap terhadap jumlah daun, jumlah akar, dan berat berangkasan segar menunjukkan adanya perbedaan yang tidak nyata $(\mathrm{P}>0,05)$ antar aksesi. Rata-rata tinggi tanaman, tingkat kehijauan daun, diameter batang semu, dan jumlah anakan pada 10 aksesi talas seperti terlihat pada Tabel 2.Perbedaan antar aksesi menunjukkan pertumbuhan talas yang berbeda.
Keragaman yang ada mencerminkan respon yang berbeda dari genotipe-genotipe talas terhadap lingkungan tumbuh, akibat pengaruh faktor genetis ataupun lingkungan. Tanaman talas tidak menuntut syarat tumbuh yang khusus. Tanaman ini dapat tumbuh pada berbagai jenis tanah pada berbagai kondisi lahan (Saidah \& Syafruddin, 2014).

Secara fisiologis tanaman yang berdaun hijau, tidak menunjukkan gejala kekurangan N. Faktor utama yang mempengaruhi klorofil dalam daun ialah pigmen yang berwarna hijau dan erat kaitanya dengan kehijauan daun tanaman (Ai \& Banyo, 2011). 
Tabel 2. Rata-rata pengukuran variabel kuantitatif pada 10 aksesi talas

\begin{tabular}{ccccc}
\hline Aksesi talas & $\begin{array}{c}\text { Tinggi tanaman } \\
(\mathrm{cm})\end{array}$ & $\begin{array}{c}\text { Tingkat kehi- } \\
\text { jauan daun } \\
\text { (unit) }\end{array}$ & $\begin{array}{c}\text { Diameter } \\
\text { batang semu } \\
(\mathrm{mm})\end{array}$ & Jumlah anakan \\
\hline Hitam & $76.66 \mathrm{a}$ & $59.05 \mathrm{ab}$ & $3.53 \mathrm{a}$ & $0.33 \mathrm{bcd}$ \\
Minyak & $73.93 \mathrm{a}$ & $61.43 \mathrm{ab}$ & $3.25 \mathrm{a}$ & $0 \mathrm{~cd}$ \\
Ketan & $67.46 \mathrm{a}$ & $59.95 \mathrm{ab}$ & $4.04 \mathrm{a}$ & $0.13 \mathrm{~cd}$ \\
Bogor & $52.05 \mathrm{~b}$ & $54.06 \mathrm{ab}$ & $3.21 \mathrm{a}$ & $0 \mathrm{~d}$ \\
Enggano 2 & $75.73 \mathrm{a}$ & $33.66 \mathrm{c}$ & $3.38 \mathrm{a}$ & $0.93 \mathrm{a}$ \\
Merpati & $71.4 \mathrm{a}$ & $64.63 \mathrm{a}$ & $3.81 \mathrm{a}$ & $0 \mathrm{~d}$ \\
Cimpul & $70.6 \mathrm{a}$ & $58.51 \mathrm{ab}$ & $4.01 \mathrm{a}$ & $0.06 \mathrm{~cd}$ \\
Jepang & $38.13 \mathrm{c}$ & $60.74 \mathrm{ab}$ & $1.21 \mathrm{~b}$ & $0.93 \mathrm{a}$ \\
Enggano 1 & $72.53 \mathrm{a}$ & $34.64 \mathrm{c}$ & $3.12 \mathrm{a}$ & $0.66 \mathrm{ab}$ \\
Melati & $64.93 \mathrm{a}$ & $50.82 \mathrm{~b}$ & $3.15 \mathrm{a}$ & $0.53 \mathrm{abc}$ \\
\hline
\end{tabular}

Keterangan : Angka-angka yang diikuti oleh huruf yang sama pada kolom yang sama berbeda tidak nyata $(\mathrm{P}>0.05)$ menurut DMRT 5\%

Hara $\mathrm{N}$ diperlukan tanaman untuk pembentukan klorofil dan merangsang pertumbuhan vegetatif tanaman seperti batang, cabang, dan daun (Prihmantoro, 1999).

Aksesi yang memiliki diameter batang yang paling besar ialah Talas Merpati dan yang paling kecil adalah Aksesi Talas Jepang. Hal ini menunjukkan bahwa aksesi Talas Jepang kurang cocok dengan lingkungan tumbuh setempat, kondisi kekurangan air, dan kurangnya pasokan unsur hara yang diberikan. Walaupun aksesi ini merupakan aksesi unggul. Menurut Yatim (1986), variasi perbedaan pada suatu individu makhluk hidup sesungguhnya disebabkan oleh dua faktor yakni faktor genetis dan lingkungan. Hasil optimum Talas Jepang pada uji adaptasi di Kabupaten Bangkep mengindikasikan bahwa kondisi lingkungan dan iklim yang cocok serta ketersediaan unsur hara yang cukup memberikan pertumbuhan Talas Jepang yang optimum pula (Saidah \& Syafruddin, 2014). Penelitian pada empat varietas kedelai menunjukkan dua varietas memiliki tingkat adaptasi yang lebih tinggi dibandingkan dua varietas lainnya (Bertham et al., 2018).

Jumlah anakan tanaman terbanyak dihasilkan oleh aksesi Talas Enggano 2 dan, Talas Jepang, yang paling sedikit oleh Talas Ketan. Sedangkan aksesi Talas Minyak, Talas Bogor, dan Talas Merpati tidak menghasilkan anakan. Aksesi talas ada yang bertipe cepat mempunyai anakan, lambat mempunyai anakan dan tidak mempunyai anakan sama sekali. Tanaman yang mengalami kekurangan air akan melakukan mekanisme ketahanan dengan mengurangi pembentukan jumlah anakan agar tanaman tetap dapat hidup (Hadisaputro, 2012). Jumlah anakan produktif menggambarkan kemampuan tanaman dalam memanfaatkan faktor lingkungan tumbuhnya secara optimum. Lingkungan tumbuh optimum adalah lingkungan yang dapat menyediakan faktor tumbuh tanaman secara optimum, seperti ketersediaan air (Sugito, 2009).
Menurut Budiarti et al. (2004) jumlah anakan per tanaman berpengaruh langsung terhadap hasil tanaman sehingga dapat dijadikan kriteria seleksi yang mempunyai anakan untuk mendapatkan genotipe talas yang berpotensi untuk dikembangkan. Semakin tinggi jumlah anakan maka kemungkinan umbi yang dihasilkan pun akan semakin bagus untuk diproduksi.

Variabel kuantitatif yang menunjukkan perbedaan yang tidak nyata $(\mathrm{P}>0,05)$ antar aksesi talas, rata-rata nya disajikan pada Tabel 3 .

Tabel 3. Rata-rata variabel jurnlah daun, jumlah akar, dan berat berangkasan segar

\begin{tabular}{lcll}
\hline Aksesi talas & $\begin{array}{c}\text { Jumlah daun } \\
\text { (helai) }\end{array}$ & $\begin{array}{l}\text { Jumlah } \\
\text { akar }\end{array}$ & $\begin{array}{l}\text { Berat } \\
\text { berangkasan } \\
\text { segar (g) }\end{array}$ \\
\hline Hitam & 5.67 & 104.26 & 394.67 \\
Minyak & 5.73 & 100,00 & 366.48 \\
Ketan & 6.00 & 59.20 & 205.75 \\
Bogor & 5.72 & 82.16 & 166.98 \\
Enggano 2 & 6.47 & 67.66 & 300.59 \\
Merpati & 5.73 & 81.53 & 280.58 \\
Cimpul & 5.60 & 79.40 & 162.17 \\
Jepang & 6.13 & 89.40 & 148.53 \\
Enggano 1 & 5.47 & 50.86 & 304.36 \\
Melati & 6.53 & 86.73 & 227.00 \\
\hline
\end{tabular}

Hasil penelitian menunjukkan bahwa jumlah daun terbanyak dihasilkan oleh aksesi Talas Melati dan jumlah daun yang sedikit ialah Talas Enggano 1. Tanaman yang memiliki jumlah daun yang banyak serta kanopi lebar akan mudah menyerap cahaya matahari sehingga cadangan makanan (karbohidrat) yang dihasilkan dari fotosintesis akan semakin banyak. 
Jumlah akar yang lebih banyak dihasilkan oleh Talas Hitam dan paling sedikit oleh Talas Enggano 1. Hal ini mengindikasikan bahwa faktor ketersediaan unsur hara dan kondisi media tanam yang optimal sangat menentukan proses pembentukan akar. Menurut Lakitan (2000), suatu tanaman akan tumbuh dengan baik dan subur bila unsur hara yang dibutuhkan tersedia dalam jumlah yang cukup dan berada dalam bentuk yang sesuai sehingga dapat diserap tanaman.

Berat berangkasan segar tanaman yang terberat dihasilkan oleh Talas Hitam (394,67 g) dan terendah Talas Jepang (148,53 g). Soegianto (2006) menyatakan bahwa variasi yang terjadi antar genotipe disebabkan karena perbedaan gen yang terdapat dalam individu tersebut. Selain itu produktivitas tanaman talas juga dipengaruhi oleh faktor lingkungan.

Berdasarkan pengamatan kerapatan stomata menggunakan mikroskop dengan perbesaran 40 kali menunjukkan perbedaan kerapatan pada masing-masing aksesi talas yang diamati (Gambar 3).

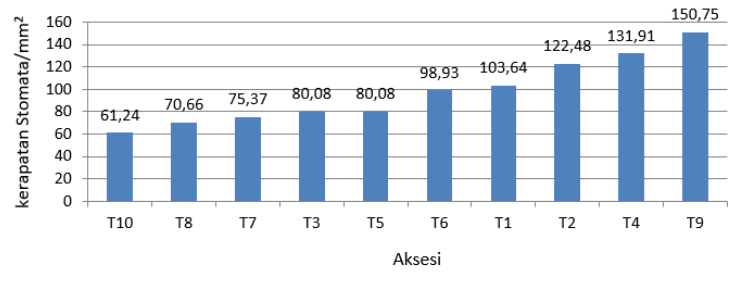

Gambar 3. Kerapatan stomata 10 aksesi talas

Keterangan : $\begin{aligned} & \mathrm{T} 1=\text { Talas hitam; } \mathrm{T} 2=\text { Talas minyak; } \mathrm{T} 3=\text { Talas ketan; } \mathrm{T} 4=\mathrm{Talas} \text { bogor; } \mathrm{T} 5=\text { Talas enggano } \\ & 2 ; \mathrm{T} 6=\text { Talas merpati; } \mathrm{T} 7=\text { Talas Cimpul; } \mathrm{T} 8=\text { Talas jepang; } \mathrm{T} 9=\mathrm{T} \text { alas enggano } 1 ; \mathrm{T} 10=\end{aligned}$ Talas melati.

Kerapatan stomata yang sedikit adalah aksesi Talas Melati, Jepang, Cimpul, Ketan, dan Talas Enggano 2, dan kerapatan stomata banyak adalah aksesi Talas Merpati, Hitam, Minyak, Bogor, dan Talas Enggano 1. Menurut Suradinata (1997), tingkat kerapatan stomata dipengaruhi oleh faktor genetik karena perbedaan genotipe seperti ketebalan daun, banyak sedikitnya bulu daun serta lokasi stomata. Kerapatan dan jumlah stomata yang banyak merupakan proses adaptasi dari tanaman terhadap kondisi penyerapan cahaya oleh daun. Stomata berfungsi sebagai pintu masuknya $\mathrm{CO}_{2}$ ke dalam daun untuk berlangsungnya fotosintesis dan penguapan air (transpirasi). Transpirasi merupakan proses yang sangat penting bagi tumbuhan karena berperan dalam meningkatkan laju angkutan air dan garam mineral, mengatur suhu daun dengan cara melepaskan panas dan kelebihan air serta mengatur turgor optimum di dalam sel (Sasmitamihardja, 1990). Jumlah kerapatan stomata sangat bervariasi dan berat berangkasan basah tanaman talas tidak bervariasi. Terlihat bahwa masing-masing aksesi memiliki habitatnya sendiri-sendiri. Oleh sebab itu kerapatan stomata sering dihubungkan dengan faktor lingkungan seperti kelembaban dan naungan.

\section{KESIMPULAN}

Hasil penelitian menunjukkan bahwa aksesi-aksesi tersebut dapat dibedakan menjadi tiga kelompok warna batang (putih: T2, T4, T5, T6, T7, T8, dan T9; pink pucat: T1 dan T3; orange kemerahan: T10); tiga kelompok warna daun (hijau: T2, T3, T4, T5, T6, T8, T9, dan T10; hijau gelap: T7; dan hijau keunguan: T1), empat kelompom bentuk daun (perisai: T1 dan T6, delta : T2, T3, dan T7, Oval : T5, T8, T9, dan T10; hati: T4); tiga kelompok ujung daun (runcing: T1, T2, T3, T4, T9, dan T10; tumpul: T5, T6, dan T7; bundar: T8); dua kelompok tepi daun (bergelombang: T1, T2, T3, T5, T6, T8, T9, dan T10; datar: T4 dan 7); dan lima kelompok wana tangkai daun (hijau: T2, T4, dan T10; hijau kekuningan: T5,T8, dan T9; hijau kebiruan: T7; hijau keunguan: T3 dan T6; hitam: T1). Analisis varian menunjukkan keragaman yang nyata antar aksesi pada tinggi tanaman, tingkat kehijauan daun, batang semu, dan jumlah anakan.

\section{DAFTAR PUSTAKA}

Ai, N.S. \& Banyo, Y. (2011). Konsentrasi klorofil daun sebagai indikator kekurangan air pada tanaman. J. Ilmiah Sains, 11(2), 167-173.

Bertham, Y. H., Aini, N., Murcitro, B. G. \& Nusantara, A. D. (2018). Uji coba empat varietas kedelai di kawasan pesisir berbasis biokompos. Biogenesis, 6 (1),36-42. https://doi.org/10.24252/bio.v6i1.4144.

BMKG. (2015). Data Curah Hujan, Suhu dan Kelembaban Sukamerindu, Sungai Serut Kota Bengkulu. Badan Meteorologi dan Geofisika Provinsi Bengkulu.

Budiarti, S. G., Y. R. Rizki \& Yudiwanti. (2004). Analisis koefisien lintas beberapa sifat pada plasma nutfah gandum (Triticum aestivun L.) koleksi Balit Biogen. Zuriat, 15(1), 31-40.

Cornell, S. E., Jickells, T. D., Cape, J. N., Rowland, A. P. \& Duce, R. A. (2003). Organic nitrogen deposition on land and coastal environments: a review of methods and data. Atmospheric Environment, 37(16),2173 -2191.https://doi.org/10.1016/S1352-2310(03)00133-X.

Gardner, F. P., Pearce, R. B., \& Mitchell, R. L. (2017). Physiology of crop plants (No. Ed. 2). Scientific Publishers.

Grist, D. H. (1986). Rice (Tropical Agriculture Series). Sixth Edition. Longman Inc., London.

Hadisaputro, S. (2012). Mengenal Beberapa Konsep Sistem Budidaya Tebu di Indonesia. Program Pelatihan Bidang Tanaman Pusat Penelitian Perkebunan Gula Indonesia, Malang.

Hafsah, Hidayat, T. \& Kusdianti. (2014). Hubungan kekerabatan kultivar Talas (Colocasia esculenta) berdasarkan karakter morfologi organ vegetatif. Jurnal Bioslogos, 4(1), 17-25. 
Hartati, N. S. \& Prana, T.K. (2003). Analisis kadar pati dan serat kasar tepung beberapa kultivar talas (Colocasia esculenta (L) Schott). Natur Indonesia, 6(1), 29-33.

Lakitan, B. (2000). Fisiologi Pertumbuhan dan Perkembangan Tanaman. PT. Raja Grafindo Persada, Jakarta.

Nurlisan, Rasyad, A. \& Yoseva, S. (2014). Pengaruh pemberian pupuk organik terhadap pertumbuhan dan hasil tanaman kedelai (Glycine max (L.) Merril). Jurnal Online Mahasiswa, Fakultas Pertanian, Universitas Riau, 1(1), 1-9.

Paiki, F. A., Yaku, A., Bagyono, F. H., Listyorini, L. M. \& Sadsoetoeboen, M. Y. (1998). Seleksi dan evaluasi plasma nutfah talas (Colocasia esculenta (L.) Schott) di Irian Jaya. Makalah Semiloka Ubiubian II, 30.

Prana, M, S. (2007). Studi biologi pembungaan talas (Colocasio esculenta (L) Schott). BIODIVERSITAS, 8(1), 63-66.

Prihmantoro. (1999). Memupuk Tanaman Sayuran. Penebar Swadaya, Jakarta.

Pusat Perlindungan Varietas Tanaman. (2006). Panduan Pengujian Individual Kebaruan, Keunikan Keseragaman dan Kestabilan. Departemen Pertanian Republik Indonesia.

Rajiman, R., Yudono, P., Sulistyaningsih, E. \& Hanudin, E. (2008). Pengaruh pembenah tanah terhadap sifat fisika tanah dan hasil bawang merah pada lahan pasir pantai bugel Kabupaten Kulon Progo. Agrin.,12(1),67-77.http://dx.doi.org/10.20884/1. agrin.2008.1 2.1.80.

Saidah \& Syafruddin. 2014. Pengaruh pupuk anorganik terhadap pertumbuhan dan hasil Talas Jepang di Kabupaten Banggai Kepulauan. Prosiding Seminar Hasil Penelitian Tanaman Aneka Kacang dan Umbi 2014. Balai Pengkajian Teknologi Pertanian Sulawesi Tengah.

Sasmitamihardja, D. (1990). Penuntun Praktikum Fisiologi Tumbuhan. ITB, Bandung

Setyowati, M., Hanarida, I. \& Sutoro. (2007). Karakteristik Umbi Plasma Nutfah Tanaman Talas (Colocasia esculenta) Balai Besar Penelitian dan Pengembangan Bioteknologi dan Sumberdaya Genetik Pertanian, Bogor. 13(2), 49-55.

Shi, Z., Li, Y., Wang, R. C., \& Makeschine, F. (2005). Assessment of temporal and spatial variability of soil salinity in a coastal saline field. Environmental Geology.,48(2), 171-178.

Sitorus, S. R. P., Kusumastuti, E., \& Badri, L. N. (2008). Karakteristik dan teknik rehabilitasi lahan pasca penambangan timah di Pulau Bangka dan Singkep. Jurnal Tanah dan Iklim.,27, 57-73.

Soegianto, A. (2006). Pendugaan potensi hasil melalui karakter morfologi pada tanaman ubi jalar (Ipomea batatas L. Lam). J. Habitat, 17(2), 92102.

Soemantri I.H., T.S. Silitonga, Zuraida N., Minantyorini, Budiarti, S.G., Suhartini T., Rais S.A., Hadiatmi, Hakim L., Dewi N. \& Setyowati, M. (2001). Rejuvenasi dan karakterisasi morfologi plasma nutfah tanaman pangan. http ://www. Indobiogen. or.id/terbitan/Prosiding/abstrak/

Prosiding2002idahanaridarejuvenasi.php.

Diakses pada tanggal 26 November 2015.

Sugito, Y. (2009). Ekologi Tanaman: Pengaruh Faktor Lingkungan terhadap Pertumbuhan Tanaman dan Beberapa Aspeknya. Universitas Brawijaya Press, Malang.

Suharno. A. K. \& Apsari S. R. (2010). Pengaruh jenis pupuk organik terhadap pertumbuhan dan produksi ubi jalar (Ipomea batatas L). J.A griekstensia, 9(2), 200-210.

Sumardi. (2008). Prinsip Silvikultur Reforestasi dalam Rehabilitasi Formasi Gumuk Pasir di Kawasan Pantai Kebumen. Prosiding Seminar Nasional Silvikultur Rehabilitasi Lahan: Pengembangan Strategi untuk Mengendalikan Tingginya Laju Degradasi Hutan. 24-25 November 2008. Fakultas Kehutanan, Universitas Gadjah Mada, Yogyakarta.

Sumarno. (1985). Analisa morfologi granula pati pada beberapa jenis talas. Jurnal Biologi Universitas Andalas, 2(4), 249-255.

Sunardi \& Sarjono, Y. (2007). Penentuan Kandungan Unsur Makro pada Lahan Pasir Pantai Samas Bantul dengan Metode Analisis Aktivasi Neutron (AAN). Prosiding PPIPDIPTN. 10 Juli 2007. Yogyakarta: Pusat Teknologi Akselerator dan Proses Bahan, Badan Tenaga Nuklir Nasional (BATAN)

Suradinata. (1997). Bentuk sel epidermis, tipe dan indeks stomata 5 genotipe kedelai pada tingkat naungan berbeda. Jurnal Biologi Indonesia, 7 (1), 67-69.

Yatim, B. (1986). Pengantar Fisiologi Tumbuhan. Gramedia, Jakarta.

Yitnosumarto, S. (1991). Percobaan Perancangan, Analisis, dan Interpretasinya. PT Gramedia Pustaka Utama, Jakarta.

Yuwono, N.W. (2009). Membangun kesuburan di lahan marginal. Jurnal Ilmu Tanah dan Lingkungan, 9 (2), 137-141. 